\title{
SMOKING HABITS OF YOUNG SOLDIERS A COMPARISON BETWEEN 1959 AND 1966 GENERATIONS
}

\author{
Lieutenant-Colonel J. P. CROWDY, \\ M.B., Ch.B., D.P.H., D.I.H., D.T.M.\&H., R.A.M.C. \\ Army Personnel Research Establishment, West Byfleet \\ Major C. J. LEWTHWAITE, \\ B.M., B.Ch., D.P.H., D.I.H., D.T.M.\&H., R.A.M.C. \\ Ministry of Defence (Army), A.M.D. 5 *
}

SUMMARY: The results of a survey carried out in 1966 into the smoking habits of 8,785 junior entrants to the Army (ages 15 to 18) have been compared with the findings of a 1959 survey of a similar age group.

At successive ages up to 15 more boys in the 1966 group had had their first smoking experience at an earlier age. Among the 1966 15-year olds there were not only more regular cigarette smokers ( 5 or more a week) than in 1959 , but more who smoked more heavily. In the older age groups $(16,17$ and 18 -year old) there were, however, significantly fewer regular smokers in 1966. Between the ages of 17 and 18 the 1966 percentage of smokers in each age group fell from 68 per cent to 63 per cent. Among the regular cigarette smokers there was a distinct trend, especially at ages 15 and 16, to heavier smoking in 1966 than in 1959. Despite the reduction since 1959 in the proportion of smokers in the population of young entrants aged 16 to 18 , there is evidence to suggest that cigarette smoking by army youth remains both more widespread and heavier than smoking by civilian boys of the same age.

\section{Introduction}

Since 1959 the Army Medical Services have sponsored research into the smoking habits of junior entrants to the Army, aged 15 to 18 . Sensitive to the criticism that military service encourages heavy smoking we have been anxious to discover the true extent of the problem, and the effects-if any-of health education, either national or local, in reducing the habit among the young. Repeated surveys of smoking habits are necessary, not only to chart the changes produced by health education but also to collect a sample of sufficient size to permit a later assessment of the effect of cigarette smoking on morbidity.

The first survey (Richards and Crowdy 1961) took place in 1959 when the Army's junior entry population was not only smaller than now, but more simply structured. On that occasion the 4,000 boys, aged from 15 to 18 were divided into two clearly defined groups-apprentices and junior leaders - the former corresponding broadly to a grammar school stream and the latter to the secondary modern. While the apprentice grouping still remains a clear-cut entity there has been a great increase in other forms of junior entrant and-as with civilian education-the secondary modern analogue is no longer appropriate. For this reason the survey now reported (1966 survey) is concerned with one large heterogeneous group of the same age range as before (although with man service starting at $17 \frac{1}{2}$ years of age there are proportionately fewer 18-year olds) which in terms of educational classification can be equated with a present-day fully comprehensive school.

*New D.A.D.A.H., HQ., UKLF, Wilton, Salisbury. 


\section{The survey}

The questionnaires for the 1966 survey were almost identical to those used in 1959 . They differed in containing a new definition of the regular smoker. In 1959 we had, following the precedent of others (Chave and Schilling 1959) adopted one cigarette a week as the criterion for regular smoking. For 1966 we decided that the figure of 1 per week was too low and increased the criterion for assessment to 5 per week. In all other respects the information requested was strictly comparable.

To avoid the possibility that untrue answers might be dictated by disciplinary pressures, especially among those under 17 years of age for whom smoking was officially forbidden, the survey was conducted in all units under confidential conditions and the boys were able to witness the sealing of completed questionnaires into return envelopes. Table I illustrates the composition of the population studied, and shows that a very

Table I

Composition of numbers sampled

\begin{tabular}{|c|c|c|c|c|c|c|c|}
\hline & & & & Year: & fage & & \\
\hline & & & 15 & 16 & 17 & 18 & \\
\hline $\begin{array}{l}\text { Total strength in a } \\
\text { Number of questio } \\
\text { Number of comple } \\
\text { Number of comple }\end{array}$ & $\begin{array}{l}\text { ge group } \\
\text { nnaires completed } \\
\text { ted questionnaires accepted } \\
\text { ted questionnaires rejected }\end{array}$ & $\begin{array}{l}a \\
b \\
c \\
d\end{array}$ & $\frac{\overline{7}}{1817}$ & $\frac{\overline{7}}{3 \overline{697}}$ & $\frac{\overline{7}}{2693}$ & $\begin{array}{l}\overline{\overline{5}} \\
-\end{array}$ & $\begin{array}{r}9699 \\
8856 \\
8785 \\
71\end{array}$ \\
\hline Per cent sample & $\frac{c}{a} \times 100$ & & & & & & $90.6 \%$ \\
\hline Per cent rejected & $\frac{-}{b} \times 100$ & & & & & & $0.8 \%$ \\
\hline
\end{tabular}

satisfactory sample of 91 per cent was achieved, with a rejection rate of less than 1 per cent.

\section{Starting to smoke}

\section{Results}

Figure 1(A) provides a direct comparison between the two generations of first smoking experience, defined as " one puff of a cigarette ". There is a small but remarkably consistent tendency for the 1966 group to start smoking younger: nearly 80 per cent of this group had had experience of cigarettes before their 15th birthday. Figure 1(B) illustrates the steady progression to regular cigarette smoking in 1966 and emphasises the finding that 52 per cent are regular smokers before they join the army. As mentioned earlier, direct comparison of the age of becoming a regular smoker is not possible, but it is interesting to note that before age 15 there was exactly the same proportion (52 per cent) smoking 5 per week in 1966 as was smoking 1 per week in the 1959 survey. In Fig. 1(B) the results for the 15 and 16-year old boys, although expressed as a percentage, are based on the returns from the older age groups and therefore represent a smaller sample than the large population of 8,724 available for the under 15 's.

\section{Regular smokers}

Based on the answers from those who were smoking more than 5 per week at the 


\section{AGE AT WHICH SUBJECTS FIRST SMOKED}
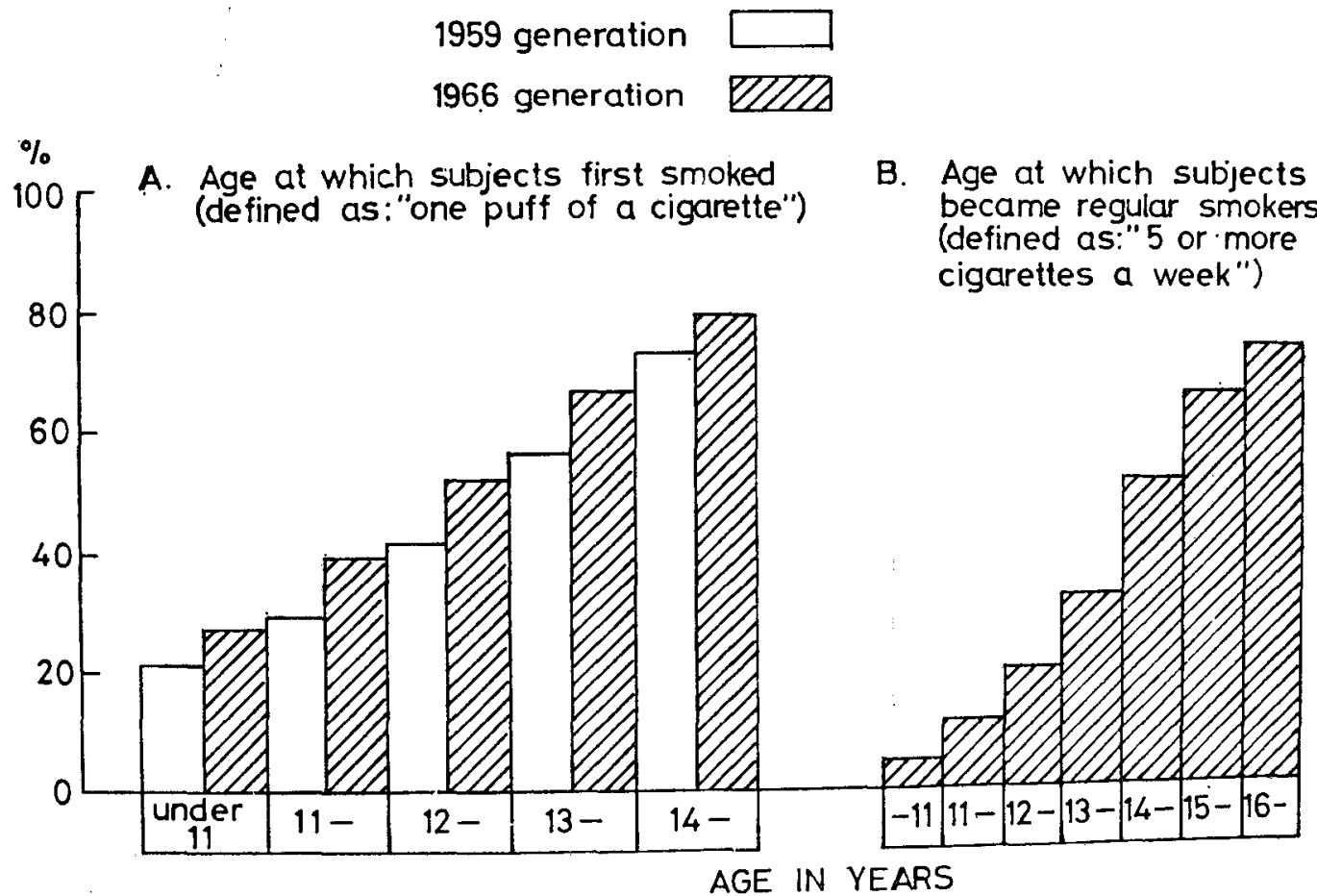

Fig. 1. Age of first smoking.

time of both surveys, Table II shows a significant change in smoking habits between 1959 and 1966. There is no statistically significant change in the habits of 15 -year olds,

Table II

Percentage of subjects who were regular smokers

\begin{tabular}{|c|c|c|c|c|c|c|}
\hline \multirow{2}{*}{$\begin{array}{c}\text { Age } \\
\text { (in years) }\end{array}$} & \multicolumn{2}{|c|}{ Number in age group } & \multicolumn{4}{|c|}{ Percentage smoking more than five per week } \\
\hline & 1959 & 1966 & 1959 & 1966 & $\begin{array}{c}\text { Difference } \\
\text { 1959-1966 }\end{array}$ & $\begin{array}{c}\text { Significance } \\
\text { of } \\
\text { Difference }\end{array}$ \\
\hline $\begin{array}{l}15- \\
16- \\
17- \\
18-\end{array}$ & $\begin{array}{r}776 \\
1518 \\
1374 \\
384\end{array}$ & $\begin{array}{r}1817 \\
3697 \\
2693 \\
578\end{array}$ & $\begin{array}{l}51.3 \\
69.7 \\
76.0 \\
77.3\end{array}$ & $\begin{array}{l}54.5 \\
63.6 \\
68.4 \\
63.3\end{array}$ & $\begin{array}{l}+3.2 \\
-6.1 \\
-7.6 \\
-14.0\end{array}$ & $\begin{array}{l}P>0.05 \\
P<0.001 \\
P<0.001 \\
P<0.001\end{array}$ \\
\hline
\end{tabular}

but within each of the three age groups from 16 to 18 there is a highly significant decrease in the percentage of regular smokers between 1959 and 1966. This decrease is not only statistically significant but, in the 18-year old age group where it reaches a maximum 14 per cent, is large enough to be of considerable practical importance. 
Habits of regular smokers

The habits of those who smoked cigarettes in the 4 weeks before the survey are displayed in Table III. This table refers to cigarette smokers only. Because a few of

Table III

Cigarette smokers

A comparison between 1959 and 1966 of all boys smoking in the 4 weeks before the survey. All figures are as a percentage of current cigarette smokers

\begin{tabular}{|c|c|c|c|c|c|c|}
\hline \multirow{2}{*}{ Age group } & \multirow{2}{*}{ Year of survey } & \multicolumn{5}{|c|}{ Percentage of smokers smoking per week } \\
\hline & & $<5$ & 5 to 9 & 10 to 19 & 20 to 39 & 40 plus \\
\hline 15 & $\begin{array}{l}1959 \\
1966\end{array}$ & $\begin{array}{l}20.7 \\
14.2\end{array}$ & $\begin{array}{l}13.3 \\
15.1\end{array}$ & $\begin{array}{l}23.3 \\
19.9\end{array}$ & $\begin{array}{l}25.3 \\
26.6\end{array}$ & $\begin{array}{l}17.3 \\
24.3\end{array}$ \\
\hline 16 & $\begin{array}{l}1959 \\
1966\end{array}$ & $\begin{array}{l}8.9 \\
6.8\end{array}$ & $\begin{array}{l}6.5 \\
5.9\end{array}$ & $\begin{array}{l}16.2 \\
13.5\end{array}$ & $\begin{array}{l}28.4 \\
27.9\end{array}$ & $\begin{array}{l}40.1 \\
45.9\end{array}$ \\
\hline 17 & $\begin{array}{l}1959 \\
1966\end{array}$ & $\begin{array}{l}5.4 \\
4.5\end{array}$ & $\begin{array}{l}4.1 \\
2.8\end{array}$ & $\begin{array}{l}9.6 \\
9.0\end{array}$ & $\begin{array}{l}22.4 \\
20.3\end{array}$ & $\begin{array}{l}58.6 \\
63.4\end{array}$ \\
\hline 18 & $\begin{array}{l}1959 \\
1966\end{array}$ & $\begin{array}{l}6.0 \\
5.2\end{array}$ & $\begin{array}{l}1.0 \\
1.0\end{array}$ & $\begin{array}{l}4.4 \\
3.9\end{array}$ & $\begin{array}{l}11.4 \\
10.9\end{array}$ & $\begin{array}{l}77.2 \\
79.0\end{array}$ \\
\hline
\end{tabular}

the cigarette smokers also smoked pipes the table tends to underestimate slightly the total burden of smoking experience, but the error is small. It can be seen from this table that there is a definite shift to the right for the 1966 group; in other words the 1966 smokers smoke more cigarettes than the 1959 group, especially in the two lower age groups. In 1966 figures were collected for those smoking up to a maximum of 70 cigarettes a week rather than the 40 per week maximum used in 1959. In 1966 it is interesting to record that no less than 30 per cent of the 17-year old and 55 per cent of the 18-year old age group were smoking 70 or more cigarettes a week.

\section{Discussion}

The findings of the present study show that between 1959 and 1966 there have been a number of small but significant changes in the smoking habits of Army youth. Up to the age of 15 more boys had started their first puff at an earlier age than in 1959 (Fig. 1). Furthermore, among the 15-year old group there were not only more smokers, but more smokers of more cigarettes in 1966 than 1959. From the age of 16 onwards the comparative picture changes (Table II). In 1966 there were fewer regular smokers in each age group from 16 to 18 years, a between generation trend which reached its peak in the 18-year old group. There is also a change in the smoking habit within each generation: in 1959 the proportion of smokers increased steadily with age: in the 1966 generation this trend was reversed for the 18-year old group in which the proportion of smokers actually fell. This diminished proportion of smokers among the older ages suggests that some external factor, possibly health education, has had an effect on the decision to smoke or not to smoke. However, for those who decided to smoke and had become committed cigarette smokers the picture is less encouraging than in 1959. The regular smokers of 1966 are heavier smokers than their counterparts of 1959. There is no simple 
explanation for this phenomenon, but the increased affluence of the 1966 young soldiers may play an important part.

Although the decrease in the proportion of regular smokers aged 16 and over between 1959 and 1966 is a most welcome sign, there is evidence that Army youth still has a less enviable record in this respect than its civilian counterpart. Our findings for 1959 and 1966 are compared in Table IV with the national statistics compiled by the

Table IV

A comparison between Army and United Kingdom male youth for 15 and 16-year old groups. Figures are expressed as a percentage of those in the age groups.

\begin{tabular}{|c|c|c|c|c|c|c|}
\hline \multirow[t]{2}{*}{ Age group } & \multirow[t]{2}{*}{ Survey and numbers } & \multirow{2}{*}{$\begin{array}{r}\text { Percentage } \\
\text { non-smokers }\end{array}$} & \multicolumn{4}{|c|}{$\begin{array}{l}\text { Percentage cigarette smokers } \\
\text { smoking per week }\end{array}$} \\
\hline & & & 5 & 5 to 9 & 10 to 19 & 20 plus \\
\hline 15 & $\begin{array}{l}1959 \text { Army }(776) \\
1966 \text { Army }(1817) \\
1968 \text { Todd }(417)\end{array}$ & $\begin{array}{l}35.3 \\
36.4 \\
56.0\end{array}$ & $\begin{array}{r}13.4 \\
9.0 \\
19.0\end{array}$ & $\begin{array}{l}8.6 \\
9.6 \\
2.0\end{array}$ & $\begin{array}{r}15.1 \\
12.7 \\
4.0\end{array}$ & $\begin{array}{l}27.6 \\
32.3 \\
18.0\end{array}$ \\
\hline 16 & $\begin{array}{l}1959 \text { Army }(1518) \\
1966 \text { Army }(3697) \\
1968 \text { Todd }(396)\end{array}$ & $\begin{array}{l}23.5 \\
31.7 \\
37.0\end{array}$ & $\begin{array}{r}6.8 \\
4.7 \\
22.0\end{array}$ & $\begin{array}{l}4.9 \\
4.0 \\
2.0\end{array}$ & $\begin{array}{r}12.4 \\
9.3 \\
4.0\end{array}$ & $\begin{array}{l}52.4 \\
50.4 \\
32.0\end{array}$ \\
\hline
\end{tabular}

Note: Army non-smokers are those who have not smoked in the past 4 weeks. Todd's non-smokers refer to both "triers" and non-smokers. The former are defined as "tried but never smoke now".

Tobacco Research Council (Todd 1969). The comparison, although not precise in terms of dates, is sufficiently apposite to demonstrate a 20 per cent excess of army smokers among the 15-year old group; the excess is much smaller for the 16-year olds. Unfortunately national figures are not available for ages 17 and 18. The considerable army excess for the 15-year old group should not necessarily be accepted at its face value. Todd's figures are based on a very small sample and may well be erroneous. Certainly the 15-year old figures are unlikely to be due to any Army influence whereas those for subsequent years-which show an improved result-could be attributed to the considerable increase since 1959 in national anti-smoking propaganda.

It is important that further surveys should be carried out because a continuation of the diminution in the proportion of young smokers found in the study could have far reaching implications for the future health of both the military and civil population.

\section{REFERENCES}

Chave, S. P. W., Schilling, R. S. F. et al (1959). Brit. J. prev. soc. Med. 13, 1. RICHARDS, H. J. A. and CRowdy, J. P. (1961). Brit. J. prev. soc. Med. $15,84$.

TopD, G. F. (1969). Statistics of Smoking in the United Kingdom. Research Paper No. 1. 5th ed. Tobacco Research Council, London. 